招待講演 1

\title{
新しい骨髄移植方法を用いた難病の治療
}

池 原進

Jpn. J. Clin. Immun., 25 (1): 7〜13, 2002.

\section{Treatment of intractable diseases by a new bone marrow transplantation method}

\author{
Susumu Ikehara
}

First Department of Pahtology, Transplantation Center, Regeneration Research Center for Intractable Disease, Kansai Medical University

\author{
Key words : autoimmune disease, \\ bone marrow transplantation, \\ hemopoietic stem cell, \\ mesenchymal stem cell, \\ intra-bone marrow injection
}

\section{I. はじめに}

骨䯚移植（BMT） は白血病，再生不良性冥血等の 造血系疾患や先天性免疫不全症, 先天的な代謝異常症 の治療方法として目覚ましい効果を挙げている．厚生 労働省指定の難病のほとんどは, 免疫が病因に何らか の形で関与しているものと考えられる。

筆者らは 17 年前から, 全身性エリテマトーデス (SLE)や慢性関節リウマチ（RA），若年性糖尿病 (IDDM) などの自己免疫疾患を自然発症するマウス を用いて, 病気の発症した自己免疫マウスに, 正常マ ウスの骨髄を移植すると，病気が治療できることを発 見した1”。

1995 年頃から欧米では自己免疫疾患の治療が主目 的の骨髄移植が開始されるようになり，すでに500 例 以上にもおよぶ難治性の自己免疫疾患の患者に対して 骨髄移植が施行されている．筆者らは，ヒトで骨䯣移 植を安全に施行するための基本的条件を明らかにし，

関西医科大学第一病理学
自己免疫疾患を含めた種々の難病を骨髄移植により治 療したいと考えて研究して来た。最近，新しい骨髄移 植の方法を開発したので，その方法も含めて紹介す る.

\section{BMT による SLE の治療}

筆者らはSLE を自然発症する種々のモデルマウス を用いて，正常マウスの骨䯣を移植することによって SLE が治療できることを発見した"1. 異系マウスの骨 䯣を移植に用いたが，これはヒトへの応用の場合，遺 伝性素因のある自己免疫疾患では，遺伝的背景を有す る同胞の骨髄よりも，正常な他人の骨髄の使用が好ま しいと考えられるからである。

以下 BMT 後の所見を要約すると，

(1) BMT 3 力月後には, 退縮していた胸腺が回復 する. (2) 血清学的にも BMT 後, 抗 DNA 抗体など の自己抗体や血中の免疫複合体が著明に減少する. (3) BMT 後, ループス腎炎の像（腎系球体の免疫グロブ リン, 補体の沈着) が改善される。このように, 正常 の骨髄を移植することにより，SLEを治療できるこ 
とが明らかになっだ1.

\section{BMT による糖尿病の予防並びに治療}

藏器特異的自己免疫疾患の1つであるI 型糖尿病 (IDDM) のモデルマウス NODを用いてBMTを行 った。すでに膵島炎を発症しているNOD マウスに正 常マウスの骨哩を移植した. BMT 後 3 力月して屠殺 前に耐糖能を調べたが，糖尿病のパターンは示さず， 膵島炎は認められず， $\beta$ 細胞の存在が確認された2).

すでに $\beta$ 細胞が完全に破壊されてしまった NOD マウスでは，BMTだけでは治療できず，BMT と膵 移植の併用による治療を試みた，筆者らは，以前，肝 移植の際に BMT を併用すると移植片が拒絶されな いということを証明しており゙，この方法を応用し て, BMT と同時に骨䯣 donor と同系マウスの胎仔の 膵を腎被膜下に移植した。この処置を受けたNOD マ ウスは, 尿糖, 血糖值も漸時低下した. 脺移植片は, 腎被膜下に生着しており，酵素抗体法により，インス リン産生細胞 ( $\beta$ 練胞) の存在が確認できだ).

次に, II 型糖尿病 (NIDDM) の中にも免疫学的異 常が関与しているものが存在するのではないかと考 え, II 型糖尿病のモデルマウス, KK-Ay を用いて BMTによるNIDDM の治療を試みた，尿糖が強陽 性の KK-Ay/Ta（H-2 b) マウスに，正常マウスの 骨髄細胞を移植した。正常 BALB/c マウスの骨䯣を 移植した群では, 正常の GTT パターンを示し, 糖尿 病は BMT のみ（膵移植なしで）治療できることが 判明した5?.

以上の結果から，II型の梼尿病も何らかの免疫学的 異常により発症し，正常マウスの骨髄を移植すること により，脺移植なしに治療が可能であるものが存在す ると考えられる，さらに，糖尿病の発症に伴って出現 してくる高脂血症, 糖尿病性腎症もBMTにより治 療可能であることが，明らかになった5).

\section{IV．BMT による慢性腎炎の治療}

慢性腎炎の中でも, 单状分節性系球体硬化症 （FGS）は，ステロイドホルモンや免疫抑制郕に抵抗 性で，予後不良とされている。

FGS のモデマウスを用いて, FGS の病因と治療 法を検討した. 蛋白尿が強陽性 $(+++)$ の FGS マ ウスに, 正常マウスの骨髄を移植すると, 移植後 6 週 より蛋白尿が次第に減少し始め, 移植 3 力月後には, 尿蛋白が痕跡程度まで改善した，腎の生検でも，光顕
所見のみならず，蛍光抗体の所見でも，腎病変が改善 されることが確認された。

次に, FGS 病変を正常マウスに移入するため, FGS マウスの部分精製した造血幹細胞を正常マウス に移植した所, 3 力月後には, 高度の蛋白尿 $(+++)$ を示すようになり，組織学的にもFGS 様 の系球体病変が認められた.このように, FGSマウ スの異常な造血幹細胞を正常マウスに移植することに よって，正常マウスにFGS 発症させ得ることに成 功した ${ }^{6}$. 以上の事実は, FGS は臟器 (腎) 特異的自 己免疫疾患であり，造血幹細胞の異常に起因すること を物語っている。

これまでのモデルマウスを用いた詳細な実駼結果に 関しては，個々の文献または筆者の英文の review ${ }^{7)}$ を参考にしていただきたい.

\section{V． 骨䯣移植成功の鍵を握る 3 種類の細胞}

種々のモデル動物を用いて正常の骨䯣を移植するこ とにより，種々の自己免疫疾患を予防ならびに治療で きることが明らかになったが，RAと SLEを自然発 症する MRL/lpr マウス（Fas gene の defectsが存 在）では，放射線に感受性であるため，8.5 Gy 以上 の放射線照射ができず，正常マウスの骨髄を移植して も，3力月以降には，自己免疫疾患が再発してくるこ とが判明した ${ }^{8)}$.この MRL/lpr マウスの自己兔疫疾 患を BMTにより根治するための方法論を模索し，3 種類の細胞 (1)多能性造血幹細胞"), (2) natural suppressor cells ${ }^{10)}$, (3) ストローマ細胞（間葉系幹細 胞）が必要であることが判明した ${ }^{11)}$.

筆者らは，多能性造血幹細胞を精製する方法を開発 し, 造血幹細胞の分化, 増殖を in vitro で解析した結 果，多能性造血幹細胞が増殖分化するためには，骨髄 の微小環境構成細胞（ストローマ細胞）が必須である ことを明らかにした。さらに, BMT の際, 造血幹細 胞とストローマ細胞（間葉系幹細胞）との主要組織適 合複合遺伝子 (MHC) の特に class I が一致してい ると, 造血幹細胞の増殖率が高いことが判明した ${ }^{122}$.

\section{VI. ドナーのストローマ細胞の補充方法}

以上の結果より, BMT の際，造血幹細胞だけでな く, donor 由来のストローマ細胞の補充が必要と考 え, 骨髄微小環境構成細胞であるストローマ細胞も donor 側と置換する目的で，先ず，骨を皮下に移植 し，骨髄細胞を静注した（図 1).8.5 Gy 放射線照射 


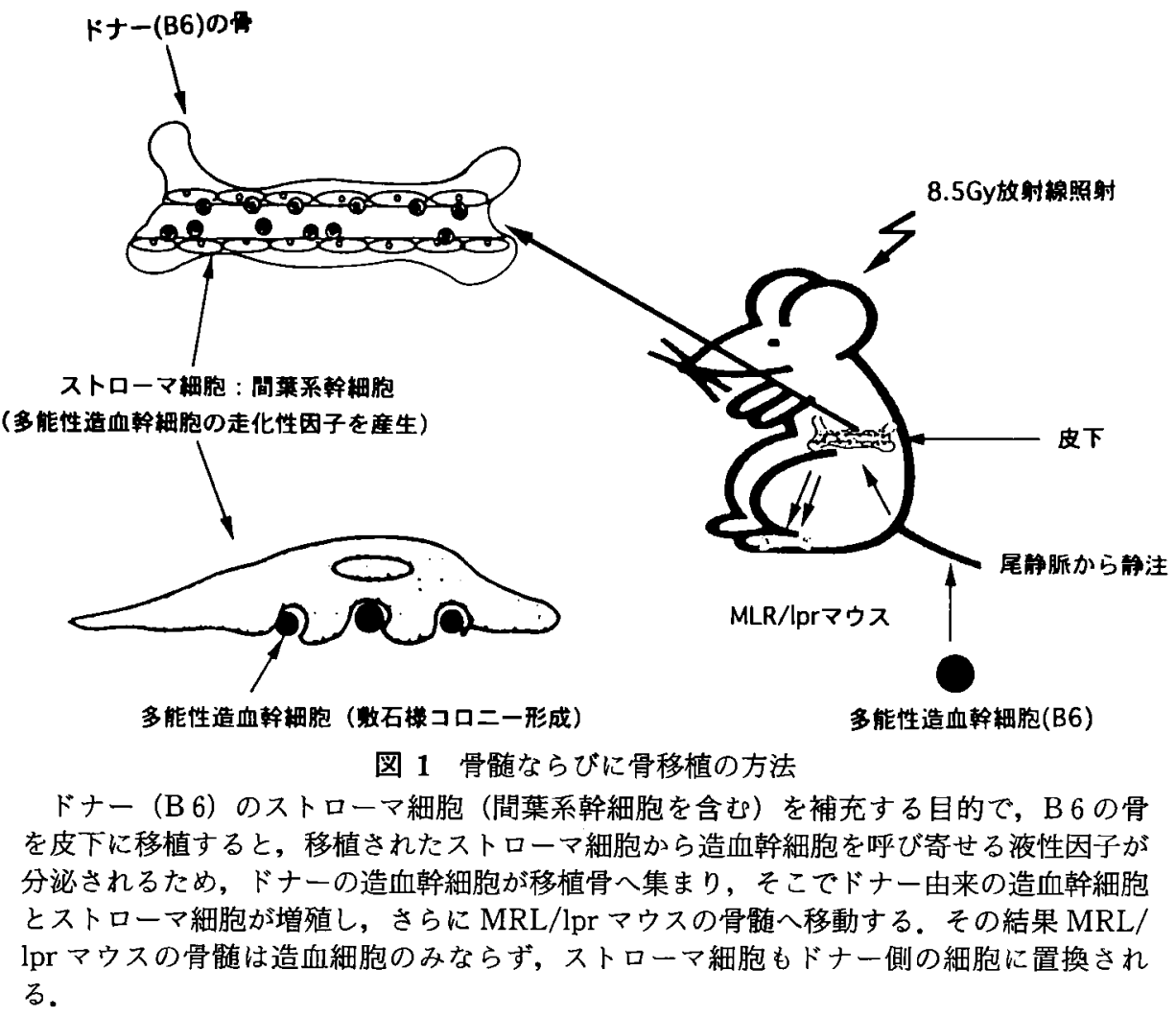

し，骨と骨䯣を同時に移植した群では，1年近く経過 しても再発せず $100 \%$ の生存率を示し, MRL/lpr マ ウスの自己免疫疾患の予防に成功した ${ }^{11}$.

しかしながら，MRL/lpr マウスは，自己免疫疾患 発症後 (尿毒症性腸炎が発症するため), 放射線に, より感受性が強くなるため, $8.5 \mathrm{~Gy}$ の放射線には耐 えられず，2 週間以内に全例死亡することが明らかに なったそこで, MRL/lpr マウスの自己免疫疾患の 治療法を検討し，放射線の分割照射 $(5 \mathrm{~Gy} \times 2)$ と 2 回の BMT（T細胞を除去せずに全骨髄細胞を移植） と骨移植と cyclophosphamide を使用することによっ て $90 \%$ 以上の生存率を得ることに成功した ${ }^{13)}$.

一般に，抗原を門脈より投与するとトレランスが誘 導され易すいということが良く知られている. 筆者 も, 最近, donor の骨髄細胞を門脈 (P.V.) より, 肝 臓へ直接注入すると免疫学的寛容が誘導され易すいこ とを見出した ${ }^{14)}$.これは, 多能性造血幹細胞自身がホ ストのCD 8+キラー細胞を anergy に陌らしめること に依ると考えられる ${ }^{15)}$.そこで，骨髄細胞をP.V.よ り投与し, MRL/lpr マウスの自己免疫疾患の治療を
試みた．図 2 に示したように, 正常マウスの骨髄細胞 を p.v. 投与とi.v.の追加投与をすることにより， MRL/lpr マウスの自己免疫疾㱏が $100 \%$ 治療可能と なった ${ }^{16)}$.この門脈内骨髄移植 (PV-BMT) が, ど うして従来の静脈内骨䯣移植 (IV-BMT) に比較し て, 効果があるかを解析した結果, PV-BMTに扔い ては, donor の造血幹細胞のみならずストローマ細胞 も肝に trap されるため, donor のストローマ細胞が donor の造血幹紼胞の增殖分化を効率良く support で きることに依るということが明らかになった ${ }^{27)}$.それ では, 韧迶外造血として肝で造血を起すよりは, 骨髄細 胞を骨髄内へ直接注入する方が，より効果があるので はないかと考えて次のような方法を開発した。

\section{VII. 骨髄内骨髄細胞移植（IBM-BMT）と 新しい骨䯣細胞採取方法}

骨髄内 (Intra-bone marrow：IBM）へ全骨骨道細 胞（少量の $\mathrm{T}$ 細胞とストローマ細胞を含む）を移植す るとdonorのストローマ細胞が donor の造血幹細胞 を効率良く support できるため, donor の造血系並び 


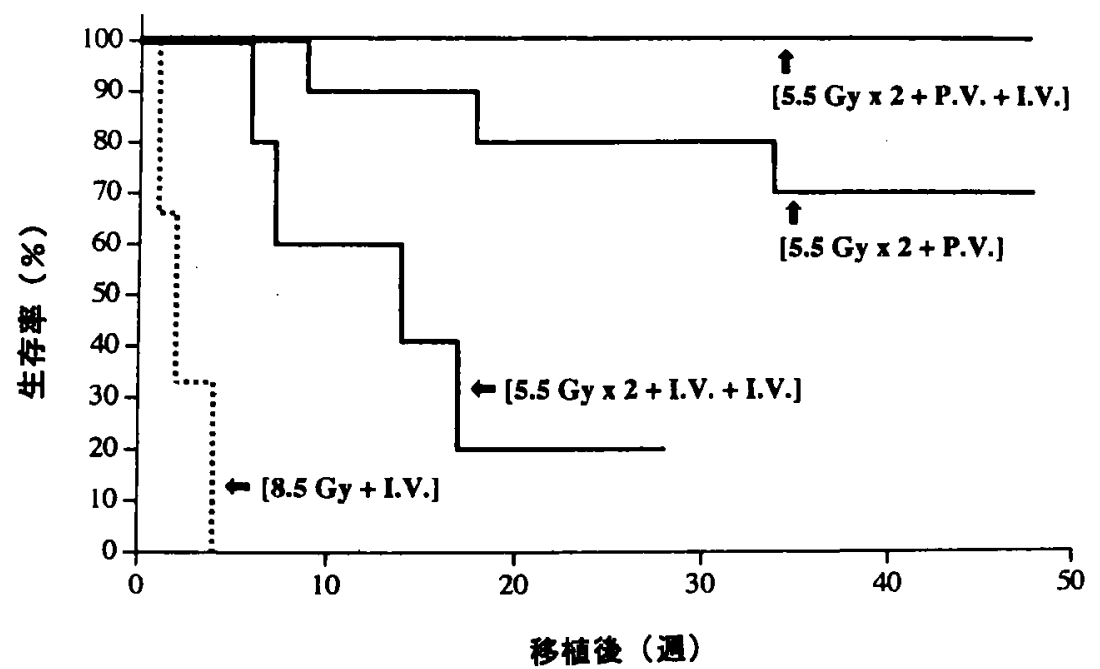

図 $2 \mathrm{MRL} / \mathrm{pr}$ マウスにおける難治性自己兔疫疾患の治療方法

経門脈投与を用いて 5.5 Gy 2 回分割照射後, 正常マウスの全骨髄細胞を門脈 (P.V.) から投与し, 5 日後に静脈（I.V.）から追加投与すると $100 \%$ の生存率が得られている.

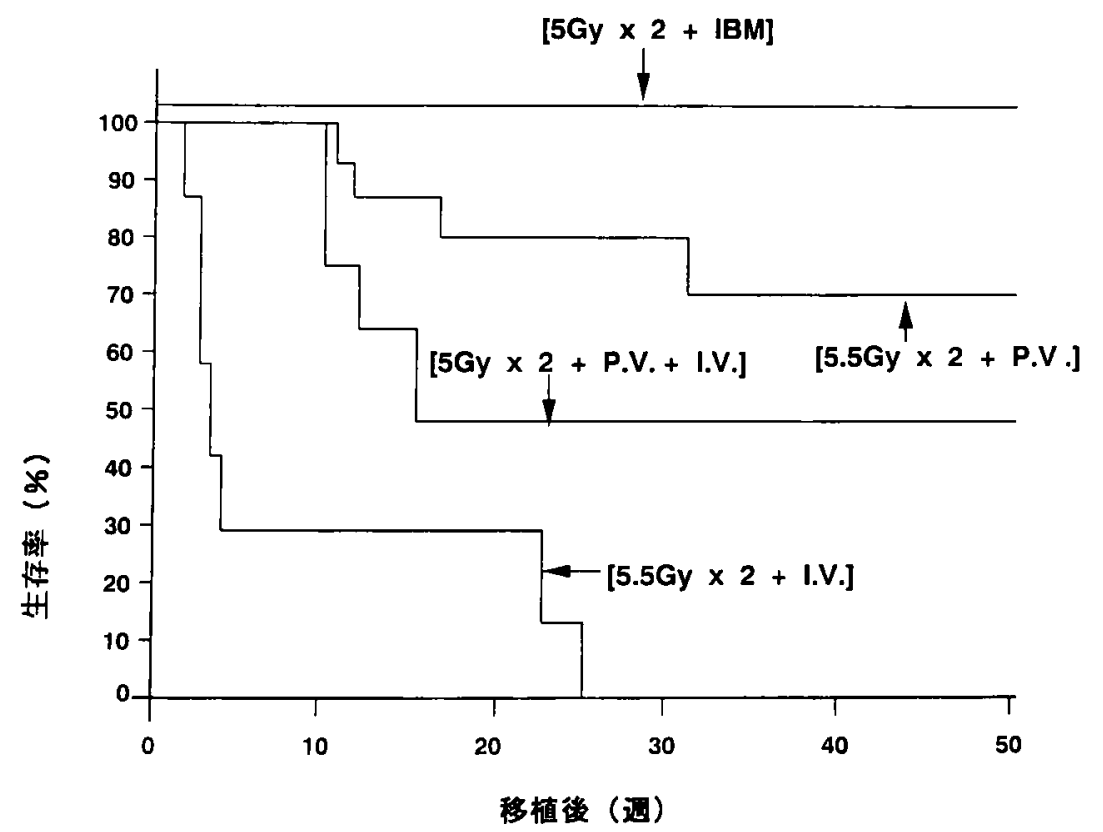

図 3 “IBM-BMT”を用いた MRL/lpr マウスの自己免疫疾患の治療 “IBM-BMT”（骨髄内骨髄移植）では，放射線照射量を $5 \mathrm{~Gy} \times 2$ に下げても 1 回の “IBM-BMT”で MRL/lpr マウスの自己免疫疾患を 100\% 治療できる.

にリンパ系細胞の回復が速やかで, 放射線量を 5.5 $\mathrm{Gy} \times 2$ から $5 \mathrm{~Gy} \times 2$ まで減量しても生着不全が起こ らないことが明らかとなっだ） (図 3).

この “IBM-BMT”をヒトへ応用するため，モン キーを用いた実験を開始し, 先ず, 骨髄細胞の新しい
採取方法を開発した，従来の腸骨よりの吸引法では， 末梢血が混入するため, 採取骨髄細胞中に $20 \%$ 以上 T細胞が含まれる。そのため $\mathrm{T}$ 細胞を除去しないと GvHD が発症する。をこで，マウスと同様に長管骨 を用いて, 灌流法を考案した (図 4) ${ }^{19}$. これは, 骨 


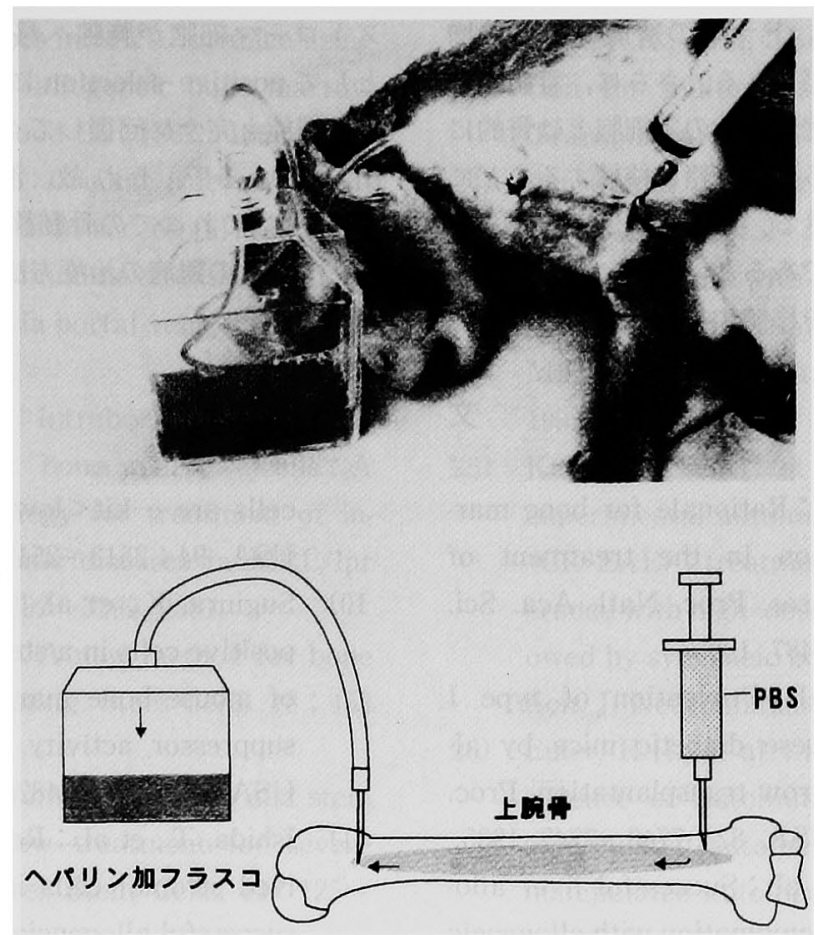

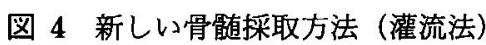

髄穿刺針を長管骨に 2 個所挿入し，一方より生食を注 入し，他方より骨髄細胞を採取するもので，短時間に 大量の骨䯠細胞を安全に採取できる. 未梢血の混入が ないため，T細胞も5\%以下で，T細胞を除去しなく ても GvHD が発症しないことも明らかになった。そ れ故, 採取全骨髄細胞を骨髄内へ注入することによっ て骨髄中の間葉系幹細胞も骨骮有内へ効率良く移植が可 能となる。

\section{BMT によるヒト自己免疫疾患の治療}

前述のように，ヒトでも BMTにより自己免疫疾 患が治療できるということが明らかになったので20), 治療抵抗性で進行性の自己免疫疾患に対しては, BMT を実施しようという国際的な動きが，7年前よ り活発となり，とりあえず，GVH 反応の起こらない autoの BMT p自己の末梢血幹細胞移植 (PBSCT) が開始された ${ }^{2123)}$.これは, 動物実験でも，抗原投 与により誘導される自己免疫疾患では, syngeneicの BMTによっても病気が改善されているからであ る ${ }^{24,25)}$. しかしながら, 抗原で誘導される自己兔疫疾 患と自然発症の自己免疫疾患とでは，病因が根本的に 異なり，前者は抗原によって誘導される，autor- eactive な $\mathrm{T}$ 細胞， $\mathrm{B}$ 細胞，抗原提示細胞の一時的な 増殖によって病気が発症してくるものであって，造血 幹細胞の異常に起因するものではない。そそのため，抗 原の消腿またはBMT の際の放射線照射により， autoreactive な免疫担当細胞が除去されることによ って病変の進行が抑制されるものと考えられる。しか しながら，後者（自然発症の場合）は，既述のよう に, 造血幹細胞の異常に起因するため, auto の BMTでは，再発をま妨れない。実際，ヒトでも auto の BMTによって自己免疫疾患の早期再発例の 報告も見られ ${ }^{26)}$ ，筆者らが，報告して来たように，七 トの自己免疫疾患の治療としては，アロのBMT，特 に同胞からの移植よりも, unrelated donors からの移 植が推奨される7).

\section{IX.おわりに}

HLA のバリアーを超えたヒトの造血幹細胞移植の 最大の問題点である GvHD の予防に関しては，筆者 らの開発した灌流法を用いて骨髄を採取することでク リアーできる.第 2 の問題点である生着不全 (HvGR) に関しては，ドナーのストローマ細胞を造 血幹細胞と一緒に骨蹎内へ直接移植 (“IBM- 
BMT”) することにより，ドナーの造血幹細胞の増 殖, 分化を促進することができる，さらに，骨䯣中に 本来存在する少量の T細胞 (末梢のT細胞とは質的に も異なると考えられている）を一緒に移植することに より, 生着不全が回避できる. 第 3 の問題点である T 細胞機能の回復が不完全であるという点に関しても, ドナーのストローマ細胞を移植すると，この骨髄中の

\section{文}

1) Ikehara, S., et al. : Rationale for bone marrow transplantation in the treatment of autoimmune diseases. Proc. Natl. Aca. Sci. USA. $82:$ 2483 2487, 1985.

2) Ikehara, S., et al. : Prevention of type I diabetes in nonobese diabetic mice by allogeneic bone marrow transplantation. Proc. Natl. Acad. Sci. USA. 82: 7743 7747, 1985.

3) Nakamura, N., et al. : Successful liver allografts in mice by combination with allogeneic bone marrow transplantation. Proc. Natl. Acad. Sci. USA. 83: 4529 4532, 1986.

4) Yasumizu, R., et al. : Treatment of type I diabetes mellitus in non-obese diabetic mice by transplantation of allogeneic bone marrow and pancreatic tissue. Proc. Natl. Acad. Sci. USA. 84:6555 6557, 1987.

5) Soe Than, et al. : Bone marrow transplantation as a strategy for treatment of non-insulin-dependent diabetes mellitus in $\mathrm{KK}-\mathrm{Ay}$ mice. J. Exp. Med. 176 : 1233 1238, 1992.

6) Nishimura, M., et al. : Faocal segmental glomerular sclerosis, a type of intractable chronic glomerulonephritis, is a stem cell disorder. J. Exp. Med. 179 : 1053 1058, 1994.

7) Ikehara, S. : Treatment of autoimmune diseases by hematopoietic stem cell transplantation. Exp. Hematol. $29: 661 \sim 669,2001$.

8) Ikehara, S., et al. : Long-term observations of autoimmune-prone mice treated for autoimmune disease by allogeneic bone marrow transplantation. Proc. Natl. Acad. Sci. USA. $86: 3306 \sim 3310,1989$.

9) Doi, H., et al. : Pluripotent hemopoietic stem
ストローマ細胞が胸腺へ移住し, thymic nurse cell として positive selectionに関与しているため, T細 胞の機能も完全に回復してくることを筆者らは最近見 出している ${ }^{27)}$. それ故, 灌流法を用いた“IBMBMT”はこれまでの骨髄移植方法に代わる画期的な 方法で種々の難病の治療方法として役立つものと確信 している.

献

cells are c-kit<low. Proc. Natl. Acad. Sci. USA. $94: 2513 \sim 2517,1997$.

10) Sugiura, K., et al. : Whea germ agglutininpositive cells in a stem cell-enriched fraction of mouse bone marrow have poten natural suppressor activity. Proc. Natl. Acad. Sci. USA. $85: 4824 \sim 4826,1988$.

11) Ishida, T., et al. : Requirement of donor-derived stromal cells in the bone marrow for successful allogeneic bone marrow transplantation : complete prevention of recurrence of autoimmune diseases in $\mathrm{MRL} / \mathrm{MP}-\mathrm{lpr} / \mathrm{pr}$ mice by transplantation of bone marrow plus bone (stromal cells) from the same donor. J. Immunol. $152: 3119 \sim 3127,1994$.

12) Hashimoto, F., et al. : Major histocompatibility complex restriction between hematopoietic stem cells and stromal cells in vivo. Blood 89: 49〜54, 1997.

13) Takeuchi, K., et al. : A new strategy for treatment of autoimmune diseases in chimeric resistant MRL/lpr mice. Blood $91: 4616 \sim$ 4623, 1998.

14) Zhang, Y., et al.: Fate of allogeneic or syngeneic cells in intravenous or portal vein injection : possible explanation for the mechanism of tolerance induction by portal vein injection. Eur. J. Immunol. $24: 1558 \sim 1565$, 1994.

15) Sugiura, $K$., et al. : Induction of donor-specific $T$ cell anergy by portal venous injection of allogeneic cells. Immunobiol. $197: 460 \sim$ 477, 1997.

16) Kushida, $T$., et al. : Treatment of intractable 
autoimmune diseases in MRL/lpr mice using a new strategy for allogeneic bone marrow transplantation. Blood $95: 1862 \sim 1868,2000$.

17) Kushida, $T$., et al. : Crucial role of donorderived stromal cells in successful treatment for intractable autoimmune diseases in MRL/ lpr mice by BMT via portal vein. Stem Cells. $19: 226 \sim 235,2001$.

18) Kushida, $T$., et al. : Intrabone marrow injection of allogeneic bone marrow cells: A powerful new strategy for treatment of intractable autoimmune diseases in $\mathrm{MRL} / \mathrm{pr}$ mice. Blood $97:$ 3292 3299, 2001.

19) Kushida, $T$., et al. : A new method for bone marrow cell harvesting. Stem Cells. $18: 453$ $\sim 456,2000$.

20) Marmont, A.M. : Immune ablation and stem cell therapy: A new treatment for severe autoimmune disease? Stem Cells. $12: 125 \sim$ 135, 1994.

21) Tyndall, A. : Hematopoietic stem cell transplantation in rheumatic diseases other than systemic sclerosis and systemic lupus erythematosus. J. Rheumatol. 24: 94 97, 1997.

22) Loske, D.J.L. : Autologous bone-marrow transplantation for rheumatoid arthrits. Lancet. $350: 337 \sim 338,1997$.
23) Burt, R.K., et al. : Bone marrow transplantation for multiple sclerosis. Bone Marrow Transplantation. 16:1 6, 1995.

24) van Gelder, M., et al. : Treatment of relapsing experimental autoimmune encephalomyelitis in rats with allogeneic bone marrow transplantation from a resistant strain. Bone Marrow Transplantation. 16:343 351, 1995.

25) Karussis, D.M., et al. : Chronic-relapsing experimental autoimmune encephalomyelitis (CR-EAE) : treatment and induction of tolerance with high-dose cyclophosphamide followed by syngeneic bone marrow transplantation. J. Neuroimmunol. $39: 201 \sim 210,1992$.

26) Euler, H.H., et al. : Early recurrence or persistence of autoimmune diseases after unmanipulated autoimmune diseases after unmanipulated autologous stem cell transplantation. Blood. 88:3621 3625, 1996.

27) $\mathrm{Li}, \mathrm{Y}$., et al. : Evidence for migration of donor bone marrow stromal cells into recipient thymus after bone marrow transplantation plus bone grafts: A role of stromal cells in positive selection. Exp. Hematol. 28:950 $\sim 960,2000$. 